\title{
THE PARADOXICAL PERCEPTION OF RELIGIOUS LEADERS AND COMMUNITY MEMBERS ABOUT ISLAM NUSANTARA
}

\author{
REZA FAHMI*, PRIMA ASWIRNA, \\ AND SYAFRUDDIN NURDIN
}

Universitas Islam Negeri Imam Bonjol Padang

\section{Abstract}

This article aims to describe the prejudices of religious leaders and community members about Islam Nusantara. This study also aims to draw the picture of people's preconceptions about Islam Nusantara and to connect the bigotry of religious leaders, the community, and its relation to the social conflict of the people of Padang. The study employes qualitative and quantitative approaches (mixing methods). The population in this study is 32 religious leaders and 168 community members. Data collection techniques employed are observation, interview, and psychological scale. The sampling method used is a simple random sampling technique. This article employed the Pearson correlation as the data analysis techniques. The results of this study found that generally the negative prejudices of religious leaders about Islam Nusantara were high. At the same time, the social conflict during society is classified as low. Meanwhile, the correlation aspect shows that there is no significant correlation between the views of religious leaders and community members about Islam Nusantara, and social conflict in society.

Artikel ini bertujuan untuk menggambarkan prasangka para pemimpin agama dan anggota masyarakat tentang Islam Nusantara. Penelitian ini juga bertujuan untuk menggambarkan prakonsepsi

\footnotetext{
* Corresponding author: Jl. Bondo No. 10, Kelurahan Air Tawar Barat, Kecamatan Padang Utara, Kota Padang, Sumatra Barat. Email: rezafahmi@uinib.ac.id.
} 
masyarakat tentang Islam Nusantara dan untuk menghubungkan kefanatikan para pemimpin agama, masyarakat, dan hubungannya dengan konflik sosial masyarakat Padang. Penelitian ini menggunakan pendekatan kualitatif dan kuantitatif (metode campuran). Populasi dalam penelitian ini adalab 32 pemimpin agama dan 168 anggota masyarakat. Teknik pengumpulan data yang digunakan adalah observasi, wawancara, dan skala psikologis. Metode pengambilan sampel yang digunakan adalab teknik simple random sampling. Artikel ini menggunakan korelasi Pearson sebagai teknik analisis data. Hasil penelitian ini menunjukkan babwa secara umum prasangka negatif para pemimpin agama tentang Islam $\mathrm{Nu}$ santara tinggi. Pada saat yang sama, konflik sosial di masyarakat tergolong rendah. Sementara itu, aspek korelasi menunjukkan bahwa tidak ada korelasi yang signifikan antara pandangan para pemimpin agama dan anggota masyarakat tentang Islam Nusantara, dan konflik sosial di masyarakat.

Keywords: religious prejudice; Islam Nusantara; social conflict.

\section{Introduction}

The presence of Islam Nusantara was considered as a revival of the identity of Indonesian nationalism in the face of waves of Transnational Islamic movements in recent years. Although Abdurrahman Wahid has expressed criticism of the transnational movement in many of his essays, the Islamicity expressed in the monolitic of the Arab style found its momentum not only politically but also culturally. Woodward (1989) explained that the transnational movement had been going on for a long time, and Islam was part of the cross-border movement at the beginning of its presence in the archipelago. The Arizona State University Professor recounted his experience when researching Javanese Islam in Yogyakarta around 1978. Woodward (1989) clarified that his research should not be generalized as Javanese Islam because the study was only conducted in a small village located 
within the fortress of the Yogyakarta Palace. He realized that Javanese Islam had a comprehensive understanding because of the variety and richness of Javanese culture both in Central Java, West Java, and East Java. He explained that the community he had met at that time was a Javanese society that made Islam an identity, but most of the Islamic rituals were not lived. However, matters relating to the Javanese tradition were still of great concern. Woodward (1989) narrates that most of these people were below the poverty line. In general, they hardly carried out the prayers, fasting, and cannot even read the Quran, even for only Sura al-Fātiha. The community was very fond of pilgrimaged to sacred graves. They also believed in talismans, the supranatural power of "keris" and rings. They made puppets for their living.

Nevertheless, Islam remains a part of its identity. At the birth and death ceremony, the community invited students from Kampung Kauman located near the village. The relationship between this community with the "Kauman" community is almost without conflict. Therefore, Woodward (1989) called it a symbiotic relationship. During its development, this community built one langgar that was managed by the Muhammadiyah religious organization. The religious lectures were given specifically on the theme of purification of theology in which all activities considered as "kejawen" were considered as violating the purity of Islam. At the same time, Muhammadiyah also opened educational institutions and health services for the surrounding community. This community sent their children to study at Muhammadiyah schools so that some of these communities started to pray and fast more diligently than before, even some of them went on pilgrimage. However, that did not mean that their Javanese tradition was reduced or stopped. For this community, their practices were not a contradiction between Javaneseness and Islam. 
According to Woodward (1989), two factors influenced this society, so there was no conflict between the Javanese and Islamic traditions. First, in the political condition of Islam in Indonesia, the presence of Muhammadiyah and Nahdhatul Ulama (NU) helped the community to identify themselves as "I am Muslim but not like Muhammadiyah or NU." Second, the boundaries of Javanese identity and Islam have been increasingly unclear. This transformation took place quickly. Some of the noble children of this community, despite studying in a Dutch school, but when they married, invited Kauman students to perform a religious ritual called "hajj".

From this research study, it can be illustrated that Islam that came at that time as a "santrification" process is part of transnational Islam. It is a form of Islam that meets with Javanese tradition where most of these traditional beliefs were considered associating God to others (shirk). But finally, even though "santrification" can influence Javanese society, it does not mean that they break up with the Javanese tradition. Instead, Islam is experiencing 'adaptation' and transforming in such a way. This is what convinced Woodward (1989) that the transnational movement would not succeed in Indonesia, until the time they were able to modify and adapt to local culture. Therefore, Woodward (1989) emphasizes that the focus of research on local Muslim wisdom in Indonesia is to enrich Islam Nusantara, not only Javanese Islam but also other local expressions of Islam in Indonesia.

However, the rejection of Islam Nusantara in West Sumatra in general and the city of Padang, in particular, was initiated by the statement of the Chairperson of the West Sumatra Council of Indonesian Ulama (MUI, Majelis Ulama Indonesia di Sumatra Barat) . Explicitly he stated, "We, the West Sumatra MUI, said without any doubt that 'Islam Nusantara' in any concept/defini- 
tion is not needed in the realm of Minang (West Sumatra)". "For us, the name 'Islam' has been perfect and does not need to be added to any appendage", he concluded the West Sumatra MUI as documented uploading Facebook account Chairman of the West Sumatra MUI. Buya Gusrizal Gazahar (General Chairman of West Sumatra Council of Indonesian Ulama) argues for the rejection of 'Islam Nusantara' is as follows. First, the term 'Islam Nusantara' invites useless debate and neglects Muslims from a variety of essential issues. The name 'Islam Nusantara', according to West Sumatra MUI, can bring confusion in understanding Islam. Second, the term 'Islam Nusantara' is also considered to contain the potential narrowing the universal meaning of Islam. Third, the term 'Islam Nusantara' is often used to refer to a tolerant Islamic religion. According to the West Sumatra MUI, tolerance is only one aspect of Islam, whereas many other points of Islam. Islam cannot be reduced to only one point but must be comprehensive. Fourth, West Sumatra MUI also considered the term 'Islam Nusantara' to have the potential to divide Muslims and bring negative views towards Muslims from other regions. Because of this, West Sumatra Nahdlatul Ulama (PWNU) Regional Leaders have invited the West Sumatra Council of Indonesian Ulama to negotiate. But until now, it has not been responded to by the West Sumatra MUI.

Departing from the pros and cons of the statement of the representative of the formal Islamic institutions (MUI) of West Sumatra, it is suspected that this rejection will produce the potential cause for social conflict between the people of Padang City, or the people of West Sumatra in general, who support the rejection of 'Islam Nusantara' and the community who supports Islam Nusantara. This is the background of why the research team are interested in studying social prejudice allegedly related to social conflict. 
The problems addressed in this research are: (1) What is the history of the development of Islam in the archipelago? (2) What are the categories of the prejudice of community leaders and community members about Islam Nusantara? (3) Is there any relationship between the religious leaders and community members of the community about Islam Nusantara and social conflicts amid society, concerning Islam Nusantara?

\section{Methodology}

This study employed qualitative and quantitative methods (mixed methods). The population in this study was 32 religious leaders and 168 community members. Data collection techniques employed are observation, interview and psychological scale. This study employed a simple random sampling technique. Data analysis techniques used is Pearson correlation.

\section{Results and Discussion}

The spread of Islam is a critical process in Indonesian history, but also the most abstract. When, why, how the Indonesian population began to embrace is still obscure. Some scholars have debated on the coming of Islam, but no definitive conclusion was possible. Generally, there are two possibilities for the process of spreading of Islam to the archipelago. First, as said by Prof. Hamka, by pointing to one of them in the news notes of Chinese travellers, that Islam entered the Archipelago (Indonesia) in the first centuries of the Hijriyah or the centuries the seventh or eighth of AD (Amrullah 1963, 72); (Mukarrom 2009, 58).

This statement is evidenced by Chinese news records that reported that on the island of Java in the seventh century AD stood the Kalingga kingdom (a Hindu kingdom) ruled by a queen named Shima. According to the news, the existence of this kingdom was heard by King Ta-Chih, who then sent a mes- 
senger to the nation. Ta-Chih is an Arabic designation given by the Chinese. As mentioned above, in about the seventh century or eight $\mathrm{AD}$, the traders from the Persian Gulf (Arabic) in the west travelled to Southeast Asia and China in the east. Muslims have already controlled the Persian gulf and some areas of India (Gujarat). Therefore, it is save to believe that most of the traders were Muslims (Mukarrom 2009, 58). Thus, the strong suspicion is that in the seventh or eighth century AD, many Muslim Arabs met Javanese and Sumatran people.

The second opinion states that Islam entered Indonesia in the 11th century AD with evidence of the grave of a woman in Leran about eight kilometres south of the town of Gresik, East Java (Ambary 2001, 54). From observations of the year number on the gravestone, it was concluded that Fātima bint Maimūn the woman who was buried died in 1082. AD. By looking at the amount of the year, it can be said that Fātima bint Maimūn had entered this region during the period of the Dhaha Kediri kingdom. The difference in opinion of the researchers also concerns the time of arrival of Islam to the archipelago. Some researchers claim that Islam came to the archipelago in the first century of the Hegira or 7th century AD, as believed by Naquib al-Attas (1972), Fatimi (1963), and Uka Tjandrasasmita (2009). For them, Islam began to develop rapidly in the 8th century AD.

Meanwhile, others believe that Islam came in the 13th century AD. However, this theory received many objections from many researchers who indicated that the 13 th century AD was a time of development and expansion of Islam to various regions of the archipelago. As a synthesis, it can be said that Islam came to the archipelago in the 7 th century AD which was marked by the establishment of Muslim villages in the 2nd century of the Hegira or the 8th century AD and expanded widely in the 13th century AD (Arsyad 2006, 76) to the West, to Banten and 
Makassar. It is believed that the form of Islam spreading in these areas is pure.

Furthermore, it is believed that two regions were first influenced by Islam, namely the Sumatra, as the port of international trade, and Java. In these regions, Islam was influential in areas not controlled by Hindu-Buddhism, such as Aceh and north-coastal of Java. Meanwhile, Islam that came to Java coincided with the heyday of the Hindu-Buddhist kingdom. Therefore Islam in Java is believed to be syncretic (Saleh 2004, 40).

\section{Qualitative Analysis Results}

Qualitative analysis is used to examine the existence of Islam in the archipelago. Islam has interacted intensively with local cultural values and norms. Today, Islam is a guide for the life of the people of the city of Padang.

\section{The fact of Developmental Islamic History}

As is the case with the above problem, differences of opinion from researchers also occur on the issue of Islamic identity, which first entered and was influential in the Archipelago. According to Ricklefs, Sufism is indeed part of Islamization, but its definite role is still not clear (Ricklefs 1994, 18).

If seen from the strong influence, Sufism occupies an essential position in the process of Islamization in the archipelago, although some researchers still doubt it. The argument of the researchers who hold on Sufism is on the aspect of Islamic flexibility, the attitude of compromise with tradition. An element of Islam that is difficult to find in the Islamic legal tradition ( $f i q b)$ both legal practices related to worldly problems and the problem of "ukhrawī", whether originating from native Indonesian religion (Animism and Dynamism) or the Hindu-Buddhist tradition (Noer 1996, 21). And the latter opinion seems to be closer to the truth. Because, Islam entered the archipelago when the posi- 
tion of Islam and Muslims in the Middle East suffered a setback due to the fall of Baghdad at the hands of the Mongol rulers in 1258 (Steenbrink 1984, 4). In this era of Islamic decline, Muslim scholars turned more to the discipline of Sufism, thus making Sufism more dominant in the horizons of Islamic thought.

It is talking about the Archipelago and Indonesia, which are both briefly refer to one region but in different situations and conditions. "Nusantara" represents the name of the early days of the existence of the region that is now called Indonesia. Archipelago comes from two words Nusa and Antara. Nusa means island or homeland, while between means distance, between, lapse, in the middle of two objects. These two words are then combined by removing the letter " $a$ " in the word "between", so that it becomes Nusantara (Ma'arif 2009, 55). With this understanding, the archipelago means the islands located between two, precisely between the two continents, Asia and Australia.

The influence of Islam in communities on the north coast of the island of Java is more prominent compared to the population of Java on the south coast. This shows that trade relations on the island of Java were quite crowded at the time, so that Islam was more pervasive, whereas in the southern part of Java, the cultural contact was infrequent, so the influence of Islam was less profound. This is evidenced by the Kraton of Yogyakarta and Solo, which is located in the southern part of the island of Java, which still survives with Javanese culture, proving that cultural contact provides an excellent opportunity for cultural influence. On the other hand, on the north coast has been heavily influenced by the nine saints of Java (Walisongo).

It is also impossible for Islam and its religious formations to force themselves to reject the culture in the archipelago. The critical role of Islamic history at the beginning of its development in Indonesia was played neatly by the saints and scholars so that 
the local community could easily accept the accommodative nature of Islam. One crucial culture is the wayang tradition that has been packaged in such a way by the saints that it can be used as a means of attracting the attention of local people to convert to Islam (Ma'arif 2007, x). Furthermore, throughout the historical records mention that the spread of Islam in the Indonesian archipelago is through trade media. With a process, we often call "Passif Penetration". It can also be said that the spread of Islam in Indonesia was not based on mission or encouragement of power, but the range of Islam took place slowly (Koentjaraningrat 1979, 260). The religion of Islam interacts with certain local cultures; there is the possibility of Islam colouring, changing, processing, and renewing local culture, maybe Islam is also coloured by local customs. Through this, the term localization process (Javanization) arises where Islamic elements in Javanese cultural literature give birth to Kejawen Islam (Simuh 2003, 8; Djamil 2000, 86). The interaction between Islam and the local culture led Javanese people to adopt beliefs or rituals and traditions from other religions including Hindu-Buddhist traditions that were considered to be in line with their thinking (Djamil 2000, 86).

\section{Polemic Islam Nusantara Between Islamic Organizations}

Dini Safitri (2015) described the "war" of rhetoric in Islam Nusantara. Islam Nusantara is cultural assimilation that has occurred in Indonesia since Islam came to the archipelago. However, in texts produced on social media, there are many pros and cons regarding the practice of cultural assimilation with Islamic values. Book with each other to make arguments, so it's like being in a war to persuade readers. The author uses a qualitative methodology to analyse the rhetoric about the text. The results showed that the war text occurred because of differences in perspective created by the Islamic organizational structure in 
Indonesia. The results of this study found before analyzing texts on the official website of NU and HTI. Researchers trace the historical background of the establishment of these two Islamic community organizations. The following is a brief explanation of the history of NU and HTI. Starting from the history of NU. History Nahdlatul Ulama was established on 16 Rajab $1344 \mathrm{H}$ / 31 January 1926, in Surabaya, with KH. Hasyim Asy'ari as "Rais Akbar" (the Great Leader). He also formulated the basic principles of NU into two books, Qanūn Asāsì (Basic Principles), and 'I'tiqād 'Abl al-Sunnah Wa al-Jama'ah (The Belief of 'Abl al-Sunnab Wa al-Jama'ah). The essence of these books came to be known as the NU's bittta, which was used as a basis and reference for NU members, in thoughts and actions in the social, religious and political fields. There are three reasons for the birth of NU, namely religious motives, nationalism motives, and motives to maintain the concept of 'Abl al-Sunnah Wa al-Jama'ah. The religious purposes behind the birth of NU are God's commands to uphold and defend religion in the archipelago and to continue the struggle of Walisongo. Also, the Dutch-Portuguese not only colonized the archipelago but also spread Christianity-Catholicism very actively. They brought Christian missionaries to various regions.

The motive for nationalism that underlies the birth of NU is a firm intention to unite clerics and religious leaders in the struggle against colonialism. The spirit of patriotism can also be seen from the name Nahdlatul Ulama, which means the Awakening of Ulama. KH. Hasyim Asy'ari as the first Rais, is known to be very nationalist. This is illustrated clearly when the NICA (Netherlands Indies Civil Administration) landed at Tanjung Perak on 25 October 1945. Before NICA landed, on 23 October 1945, KH. Hasyim Asy'ari, on behalf of NU, stated the call or called for "jihād fī sabīlillāh" (struggle on Allah's 
way) to all NU citizens, who later became known as the "Jihād Resolution". There are three critical points in the "Jihād Resolution": a) First, every Muslim - even - old, young and poor, will fight the infidels who are hampering Indonesian independence. b) Second, fighters who die in the war of independence deserve to be called martyrs. c) Third, Indonesian citizens who side with the invaders are considered to divide national unity and must be sentenced to death. The fatwa made Indonesian Muslims at that time obliged to defend the motherland. It is deemed to be unlawful if backed away when we are dealing with invaders within a radius of $94 \mathrm{~km}$ (the distance is adjusted to the ability of plural "qașr", shortening of Prayers). The fatwa of Jihād, written in Pegon script and disseminated its appeal by Bung Tomo via RRI Surabaya radio. Hearing the call of "jihād" that was spread by Bung Tomo, the citizens of Surabaya and East Java were burning to fight against the invaders.

Thousands of chaplains and students from various regions came to Surabaya. The incident occurred on November 10, 1945, which was then commemorated as the heroic day for the Indonesian people (Ricklefs 2008). The clerics and warriors formed a line of Sabīlillāh troops led by KH. Maskur. The students and youth formed the Hizbullāh forces led by H. Zainul Arifin. While the elderly chaplains formed the Mujahideen ranks led by $\mathrm{KH}$. Wahab Hasbullah. This resistance bore fruit, namely the killing of the colonial leader, Brigadier General Mallaby. The motive to maintain the concept of "Ahlu al-Sunnah wa al-Jamā'ah" (Aswaja) which was the background of the birth of NU, is to fortify Muslims, especially in Indonesia to remain faithful to the teachings of Islam "Ahlu al-Sunnah wa al-Jamā'ah", which means followers of the Sunnah of the Prophet, the Prophet's companions, and "Salaf" ulama followers (followers of the Prophet-Companions), so as not to be tempted by new teachings that were not 
known at the time of the Apostles-Salaf al-Sāliḥ/teachings of heresy experts. Meanwhile, at the NU 27th Conference in 1984, the 19th NU "hitța" was rolled out.

\section{Quantitative Analysis Results}

Considering that the research carried out is (mixing methods), which is a method of analysis that combines qualitative and quantitative approaches, the explanation of each method used is explained below:

\section{Descriptive Analysis}

This section will explain the respondents' characteristics based on sex, age, occupation, and income.

\section{Table 1}

\section{Characteristics of Respondents}

\begin{tabular}{|c|c|c|c|c|}
\hline No & $\begin{array}{l}\text { Respondent Charac- } \\
\text { teristic }\end{array}$ & Category & Sum & Percentages \\
\hline \multirow[t]{3}{*}{1} & \multirow[t]{2}{*}{ Gender } & Male & 187 & 93,50 \\
\hline & & Female & 13 & 6,50 \\
\hline & General Sum & & 200 & 100,00 \\
\hline \multirow[t]{4}{*}{2} & \multirow[t]{3}{*}{ Age } & $20-30$ years old & 21 & 10,50 \\
\hline & & $\begin{array}{l}31 \text { then }-41 \\
\text { years old }\end{array}$ & 51 & 25,50 \\
\hline & & $\geq 42$ years old & 128 & 64,00 \\
\hline & General Sum & & 200 & 100,00 \\
\hline \multirow[t]{3}{*}{3} & \multirow[t]{2}{*}{ Occupation } & PNS & 38 & 19,00 \\
\hline & & Swasta & 162 & 81,00 \\
\hline & General Sum & & 200 & 100,00 \\
\hline \multirow[t]{4}{*}{4} & \multirow[t]{3}{*}{ Salary } & $\leq \mathrm{Rp} 800.000,-$ & 27 & 13,50 \\
\hline & & $\begin{array}{c}\text { Rp } 1000.000-R p \\
.200 .000,-\end{array}$ & 105 & 52,50 \\
\hline & & $\geq \operatorname{Rp} 3000.000,-$ & 68 & 34,00 \\
\hline & General Sum & & 200 & 100,0 \\
\hline
\end{tabular}

Resources: Research Project 2019

Based on the data in Table 1 above, it is found that the ma- 
jority of respondents are male. Then the age range of most respondents is $\geq 42$ years. Furthermore, the occupations owned by respondents generally work in the private or entrepreneurial sector. While in the aspect of income, it is obtained that typically they earn less than Rp 1,000,000 up to Rp 2,000,000.

\section{Reliability Test}

There are three stages carried out in the quantitative analysis process carried out in this study, including (1) Testing the validity and reliability of research instruments. (2) Testing the spread of min and the percentage of prejudices of religious leaders and community members about Islam Nusantara. Then the range of min and portion of social conflicts that occur amid society. (3) Testing the research hypothesis. Based on the results of the validity and reliability test using Cronbach alpha obtained reliability values of 0.817 (Prejudice) and 0.826 (social conflict) means that the reliability level of the instrument in the form of psychological scale is quite reasonable and appropriate to use.

\section{Min and Percentage Spreads}

This test is needed to see the tendency of the average distribution of prejudices of religious leaders and community members about Islam Nusantara. Then what about the spread of min and the percentage of social conflicts that occur during society. This can be seen in Table 2 .

Table 2

Mean and Percentage of Prejudice and Social Conflicts

\begin{tabular}{llll}
\hline Variable & Category & Sum & Percentage \\
\hline Prejudice & High & 173 & 86,50 \\
\hline General Sum & Low & 27 & 13,50 \\
\hline Social Conflicts & & 200 & 100,00 \\
\hline General Sum & High & 12 & 6,00 \\
\hline
\end{tabular}

Resources: Research Project 2019 
Based on Table 2, it is found that generally, prejudice (injury or damage resulting from some judgment or action of another in disregard of one's rights, i.e. especially: detriment to one's legal rights or claims) among religious leaders and community members is high $173(86.5 \%)$, whereas social conflict in the community was classified as low, namely 188 (94\%). This means that the prejudices of community leaders and members of the city towards Islam Nusantara are high, where they assume that Islam Nusantara is primordial, anti-Arab, and even racist as a new strategy from the Liberal, Western and Zionist Islamic Networks. However, religious leaders and community members generally assume that social conflict is relatively low, meaning that they do not want social conflict amid society from differences in views about Islam Nusantara. They do not want to be involved in empirical disputes. They will bring social upheaval, which certainly will not benefit the social life of the people of the city of Padang, especially, then the people of West Sumatra in particular.

\section{Hypothesis test}

Furthermore, the results of testing the hypothesis obtained by the picture that there is no significant relationship between the prejudice of religious leaders and community members with social conflicts that occur during society. This means that discrimination tends to be moderate to the contradiction between the pros and cons of Islam Nusantara. This can be seen in Table 3.

Table 3

Correlation Table Between Prejudice and Social Conflict

\begin{tabular}{llll}
\hline & & Prejudice & Social Conflicts \\
\hline Prejudice & Pearson Correlation & 1 &, $008(* *)$ \\
\hline & Sig. $(2$-tailed) & &, 000 \\
\hline
\end{tabular}


FAHMI, ASWIRNA, AND NURDIN

\begin{tabular}{llll}
\hline & $\mathrm{N}$ & 200 & 200 \\
\hline Social Conflicts & Pearson Correlation &, $008(* *)$ & 1 \\
\hline Sig. (2-tailed) &, 000 \\
\hline $\mathrm{N}$ & 200 & 200 \\
\hline$*$ Correlation is significant at the 0.01 level (2-tailed).
\end{tabular}

Based on the analysis in Table 3, an illustration is obtained that the Pearson correlation test (product-moment) found that the $r$ count is 0.008 . While the value of $r$ table is 0.221 . So $r$ count $<\mathrm{r}$ table, Ho = Rejected, meaning that there is no relationship between the prejudice of religious leaders and community members with social conflicts about Islam Nusantara. This means that the two variables or variables, namely: Prejudice of religious leaders and members of the community with social conflicts each stand alone. Where even though prejudice that rejects or contradicts the Islamic archipelago, does not give effect to social conflicts that occur in the midst of society.

This shows that the people of Padang City are not easily deceived and want to be physically involved in opposing views about Islam Nusantara. Society is rational and impartial and tends to be pragmatic in assessing the value of social problems. Prejudice does not give birth to social conflict but is considered as a different point of view that needs to be respected from the rules of nation and state. Egalitarian in a context where religious leaders are only a symbol of power from Islamic institutions legally recognized (such as the Council of Indonesian Ulama) which needs to be respected and respected. But the community has its independent logic and is not quickly intervened by formal religious institutions. Pragmatic here lies in the fact that social conflict, even if considered a wise step in favour of religious authority holders, does not assume that this is a solution that benefits the community. Even social conflict has only a counterproductive impact on social life. 


\section{Conclusion}

The perception of religious leaders and community members about Islam Nusantara was categorized high. It means that most of the respondents think that Islam Nusantara can not accept as an idea because Islam Nusantara looks like a new paradigm of Islam, which implemented contrary to Islamic values. But On another hand, some of the people and community members also support the idea of Islam, Nusantara. It mentions that there was the contradictory idea of Islam Nusantara in society. Besides that, the social conflict did not exist as the implementation of the paradoxical plan of Islam Nusantara. It happened because of the rational thinking pragmatism logic and independent attitude as a value in society. Rational means that conflict in the community will be damage society, so they don't want to join the battle. Pragmatism idea means that people don't want to join the conflict because it will cost to the nation, not only economically cost but also has a social cost to the community.

\section{Appreciation}

The research team gave a great appreciation to the Ministry of Religious Affairs of the Republic of Indonesia for funding this research. With the support of these funds, the implementation of the study could be carried out. I am also indebted to the informants and respondents involved in the study.

\section{Bibliography}

Al-Attas, Syed Muhammad Al-Naquib. 1972. Islam Dalam Sejarah Dan Kebudayaan Melayu. ABIM.

Ambary, Hasan Muarif. 2001. Menemukan Peradaban: Jejak Arkeologis Dan Historis Islam Indonesia. Ciputat: PT Logos Wacana Ilmu. 
Amrullah, Abdul Malik Karim. 1963. "Sejarah Masuknya Islam Ke Indonesia." In Masuk Dan Berkembangnya Agama Islam Di Daerah Pesisir Di Sumatra Utara. Medan.

Arsyad, Azhar. 2006. "Kedatangan Dan Perkembangan Islam Di Nusantara Dengan Damai." In Menjadi Indonesia: 13 Abad Eksistensi Islam Di Bumi Nusantara, by Komaruddin Hidayat. Jakarta: Mizan.

Djamil, Abdul. 2000. Islam Dan Kebudayaan Jawa. Yogyakarta: Gama Media.

Fatimi, Sayyid Qudratullah. 1963. Islām Comes to Malaysia. Singapore: Malaysian Sociological Research Institute.

Koentjaraningrat. 1979. Pengantar Antropologi. Jakarta: Aksara Baru.

Ma'arif, Ahmad Syafi'i. 2007. "Sublimitas Islam Di Indonesia." In Islam Nusantara, by M. Abdul Karim, Faal Fahsin, and Artika Maya. Yogyakarta: Reader Book Publisher.

- 2009. Islam Dalam Bingkai Keindonesiaan Dan Kemanusiaan: Sebuah Refleksi Sejarah. Bandung: PT Mizan Publika.

Mukarrom, Ahwan. 2009. Sejarah Islamisasi Nusantara. Surabaya: Jauhar.

Noer, Deliar. 1996. Gerakan Moderen Islam Di Indonesia, 19001942. Jakarta: LP3ES.

Ricklefs, Merle Calvin. 1994. Sejarah Indonesia Modern. Yogyakarta: Gadjah Mada University Press.

- 2008. A History of Modern Indonesia since c. 1200. 4th ed. UK: Macmillan International Higher Education.

Safitri, Dini. 2015. "Debat Retorika Dalam Wacana Islam Nusantara.” Jurnal Commlinevol, 163-78. 
Saleh, Fauzan. 2004. Teologi Pembaruan: Pergeseran Wacana Islami Sunni Di Indonesia Abad XX. Jakarta: Serambi Ilmu Semesta.

Simuh. 2003. Islam Dan Pergumulan Budaya Jawa. Bandung: Mizan Media Utama.

Steenbrink, Karel Andrian. 1984. Beberapa Aspek Tentang Islam Di Indonesia Abad Ke-19. Jakarta: Bulan Bintang.

Tjandrasasmita, Uka. 2009. Arkeologi Islam Nusantara. Kepustakaan Populer Gramedia.

Woodward, Mark R. 1989. Islam in Java: Normative Piety and Mysticism in the Sultanate of Yogyakarta. Tucson: The University of Arizona Press. 
This page intentionally left blank 